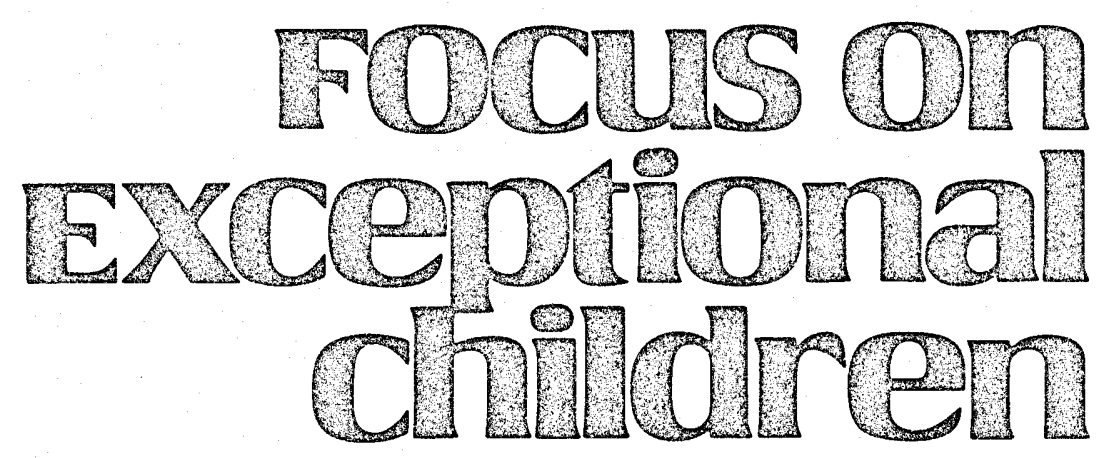

\title{
Comprehensive Curriculum for Students With Mild Handicaps
}

\author{
Edward A. Polloway, James R. Patton, Michael H. Epstein, and Thomas E.C. Smith
}

The most critical programming consideration in classes for individuals with mild learning handicaps is, without question, what is to be taught-the curriculum. Regardless of the effectiveness and efficiency with which instruction may be provided, ultimately the overall benefit of the school experience will be derived from the curriculum-that is, the planned learning experiences that have intended educational outcomes (Hoover, 1988). In considering the development of programs for students who are mildly handicapped, the importance of a comprehensive curriculum should be apparent inasmuch as the primary goal is to develop an outcomes-focus that is consistent with the diverse needs of these students. The focus of this article is on students with mild learning problems across all grade levels. Major curricular issues, however, become most significant at the secondary level. For our purposes, comprehensive curriculum is derived from a concept advocated by Polloway, Patton, Payne, and Payne (1989) and thus refers to a program that is:

- responsive to the needs of an individual student at the current time;

-consistent with the objective of balancing maximum interaction with nonhandicapped peers against critical curricular needs;

-integrally related to service delivery option (i.e., resource programs, selfcontained classes, and modified models);

\footnotetext{
Edward Polloway is Professor of Education and Human Development, Associate Dean of the College, Lynchburg College, VA. James Patton is Associate Professor of Special Education, University of Hawaii. Michael Epstein is Professor of Special Education, Northern Illinois University. Thomas Smith is Professor of Special Education and Vocational Rehabilitation, Sparks Center, University of Alabama at Birmingham.
} 
-derived from a realistic appraisal of potential adult outcomes of individual students;

-focused on transitional needs across the life-span;

- sensitive to graduation goals and specific diploma track requirements.

The importance of this topic at the secondary level has been articulated by many teachers anecdotally, identified through studies of secondary special education settings (e.g., Halpern \& Benz, 1987), and can be inferred from discouraging national statistics on graduation, drop-out, and employment rates (e.g., Department of Education, 1987; Edgar, 1987; Neel, Meadows, Levine, \& Edgar, 1988). The recurring need is for innovative and relevant curricula that address the features listed above.

Three major topics are the focus of this article. Initially a description is presented of current and emerging curricular models for students with learning-related disabilities, accompanied by an evaluation of their effectiveness. Second,

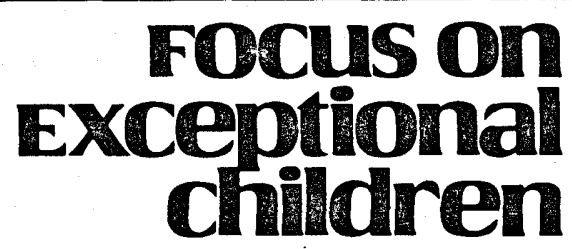

FOCUS ON EXCEPTIONAL CHILDREN (ISSN0015-511X) (USPS 203-360) is published monthly except June, July, and August as a service to teachers, special educators, curriculum specialists, administrators, and those concerned with the special education of exceptional children. This publication is annotated and indexed by the ERIC Clearinghouse on Handicapped and Gifted Children for publication in the monthly Current Index to Journals in Education (CIJE) and the quarterly index, Exceptional Children Education Resources (ECER). It is also available in microform from Xerox University Microfilms, Ann Arbor, MI. Subscription rates: Individuals, \$24 per year; institutions, $\$ 30$ per year. Copyright (C) 1989, Love Publishing Company. All rights reserved. Reproduction in whole or part without written permission is prohibited. Printed in the United States of America. Second class postage is paid at Denver, Colorado.

POSTMASTER: Send address changes to:

Love Publishing Company

Executive and Editorial Office

1777 South Bellaire Street

Denver, Colorado 80222

Telephone (303) 757-2579

\section{EDITORIAL BOARD}

Edward L. Meyen

University of Kansas

Richard J. Whelan

University of Kansas Medical Center

Stanley F. Love

Publisher
Carolyn Acheson Senior Editor the decision-making process vìs-a-vìs curricular model selection is discussed. Third, the programmatic needs of identifiable subgroups of students with mild handicaps are reviewed and related to specific curricular models and combinations of models.

\section{ALTERNATIVE ORIENTATIONS}

Three general curricular orientations can be identified as a basis for programming with students who are mildly handicapped (Polloway et al., 1989; Vergason, 1983). Although these orientations have been defined differently, they include: (a) remediation focusing on academic skills remediation and social adjustment, respectively; (b) maintenance models, including tutoring as well as programs emphasizing the acquisition and utilization of learning strategies; and (c) functionality, inclusive of vocational training efforts and programs oriented to the transition from adolescence to adulthood. Figure 1 schematically presents the models in relation to traditional service delivery options. These three general orientations, discussed next, provide a basis for the subsequent discussion of the curricular needs of specific subgroups of students.

\section{Remediation}

\section{Academic Remediation}

A basic skills model primarily emphasizes the remediation of academic deficits, thus directly addressing apparent student needs. This approach provides the core for most elementary special education curricula. Reviews of student IEPs suggest that middle school programs are also primarily remedial/academic in focus (McBride \& Forgnone, 1985). Basic skills programs have a long-term orientation because they presume that instruction in such skills ultimately will increase students' academic achievement levels and enable them, at least, to reach minimal functional literacy.

The major advantage of the remedial approach is that skill deficiencies are identified and intervention subsequently can be provided to increase performance in these problematic areas. Although not all basic skill programs have equal effectiveness, those that incorporate the tenets of effective instructional practice (Stevens \& Rosenshine, 1981) have empirically demonstrated substantial gains in achievement. This issue is of greatest importance when consideration is given to programming for adolescents.

For example, the Corrective Reading Program (CRP; Engelmann, Becker, Hanner, \& Johnson, 1980), based on 
Special Class

Resource Services

Regular Class
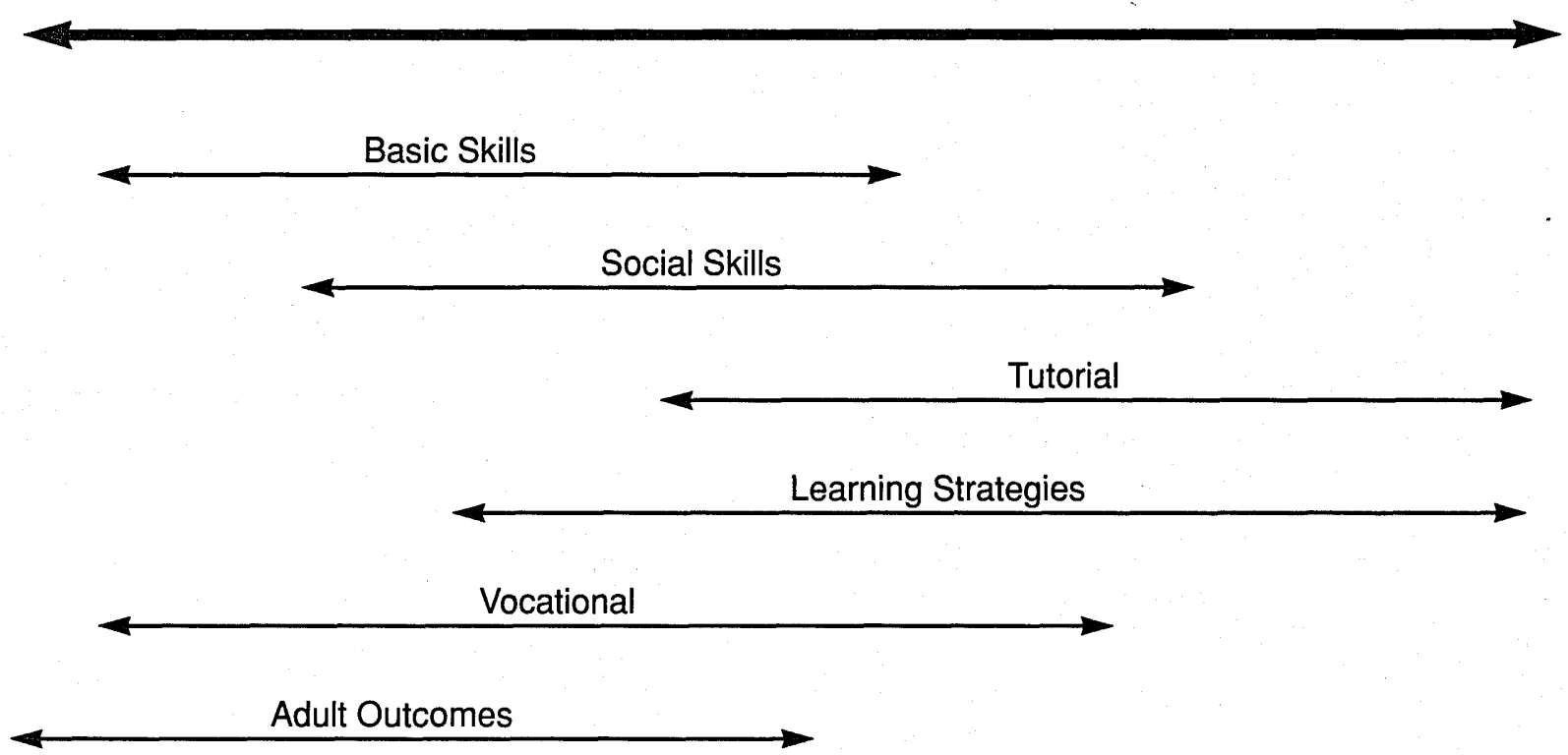

FIGURE 1

Relationships of Curricular Orientations to Service Delivery Models

the principles of direct instruction, was specifically designed for middle school and high school students who continue to experience difficulties in basic reading recognition and comprehension skills. A growing body of research on CRP (e.g., Campbell, 1983, cited by Becker, 1984; Gregory, Hackney, \& Gregory, 1982; Polloway, Epstein, Polloway, Patton, \& Ball, 1986; Thorne, 1978) offers evidence that it can be effective with older students identified as learning disabled or mildly retarded or those who are generically referred to as slow learners.

The research on Corrective Reading reinforces the premise that, when enrolled in intensive instructional programs, a large number of adolescents with disabilities may be able to benefit from academic remediation (Meyen \&
Lehr, 1980). It is instructive to consider what Meyen and Lehr (p. 23) identified as the characteristics of intensive instruction that would predict positive gains by students:

1. consistency and duration of time on task;

2. timing, frequency, and nature of feedback based on the student's immediate performance and cumulative progress;

3. regular and frequent communication by the teacher to the student of his or her expectancy that this student will master the task and demonstrate continuous progress;

4. pattern of pupil-teacher interaction in which the teacher responds to student initiatives and uses 
consequences appropriate to the responses of the student.

It can be concluded that remedial approaches may be successfully used with many students when attention is paid to certain principles of implementation. Additionally, benefits are enhanced when these approaches are balanced with attention to life skill needs. Even relatively small gains in certain skill areas such as reading may have a significant effect on a young adult's ability to function more competently in community settings.

Although the basic skills approach is in many ways attractive, several problems may emerge as a result of its use, especially when extended beyond the elementary school level. First, a remedial orientation often neglects students' specific strengths by focusing entirely on deficit areas. Second, it may fail to address issues of transfer of learning, whether defined as generalization to the regular class setting or to various post-school environments including postsecondary education and work settings. Additionally, sole reliance on a basic skills model without attention to other critical areas may be inappropriate for many students at the secondary level in that other skills (e.g., life skills, functional skills) are ignored or are only partially taught.

As a result of these concerns, more and more people have questioned the value of continued reliance on a basic skills model with adolescent learners (e.g., Alley \& Deshler, 1979; Deshler, Schumaker, Lenz, \& Ellis, 1984). Alternative programmatic options must be considered, especially for students who have been in an instructionally sound, intensive remedial program but who have failed to progress.

\section{Social Skills and Adjustment}

This remedial model is characterized by an emphasis on the development of social competence, typically recognized as critical to life adjustment (Epstein \& Cullinan, 1987). The basis for classification as remedial is that it represents a deficit view of the traits of individual students. When this orientation has served as the core of curricular efforts, it most often has been within programs for students identified as emotionally disturbed or behaviorally disordered (Masters \& Mori, 1986; Zigmond \& Brownlee, 1980).

More generally, and of significant importance to special educators, the success or failure of students with mild handicaps in regular classes is related to social competence. For example, Gresham $(1982,1983,1984)$, who reviewed over 40 studies on the integration of pupils with mild handicaps, reported that children with handicaps interact infrequently and, to a large extent, negatively with their nonhandicapped peers. He argued convincingly that many pupils have been placed in mainstream settings without the necessary social skills to succeed in these environments and to gain acceptance by their peers.

Three approaches have been associated with social adjustment: social skills acquisition, behavioral change, and affective education. Although each represents a somewhat distinctive focus, they are grouped together here, as all relate to the overall goal of social adjustment.

Social skills have been defined as "responses which, within a given situation, prove effective, or in other words, maximize the probability of producing, maintaining, or enhancing positive effects for the interactor" (Foster \& Ritchey, 1979, p. 626.). Therefore, training efforts focused on social skills acquisition are concerned with the attainment of skills necessary for students to overcome situations in classrooms, on the job, and in other areas that prevent assimilation (Masters \& Mori, 1986).

The behavioral change strategy focuses on identifying a target behavior and implementing a reinforcement system that will lead to permanent change in a behavior. Steps in the behavior change are: (1) selecting the target behavior, (2) collecting baseline date, (3) identifying reinforcers, (4) implementing a procedure for reinforcing appropriate behaviors; and, (5) evaluating the intervention.

Affective education differs in that it emphasizes selfcontrol and the relationship between self and others in the environment (Shea \& Bauer, 1987). A primary emphasis frequently is placed on emotional aspects of social adjustment.

Several considerations are important relative to the issue of effectiveness for the social adjustment orientation. First, any program should be accountable for observable and meaningful change in students. Unfortunately, some social adjustment programs, especially those focused on affective education, have generated little evidence of documented change in skills or behavior. Additionally, the effectiveness of most social skills curricula remains largely unknown (Epstein \& Cullinan, 1987). A second concern has to do with generalizability of the programs. To justify their use, social adjustment programs must demonstrate that they can contribute to student success in subsequent environments. This may be defined in terms of transfer to regular classes or generalization to environments beyond the school setting.

For example, one program that stresses transfer is the School Survival Skills Curriculum, developed at the Learning Research and Development Center at the Uni- 
versity of Pittsburgh (see Zigmond \& Brownlee, 1980; Zigmond \& Sansone, 1986). The curriculum includes attention to classroom behavior, study skills, and teacherpleasing behaviors.

A beneficial approach to the issue of generalizability of program outcomes has come through the use of cognitive approaches to behavior change and social skills acquisition (see Meichenbaum, 1980, 1983). Such programs, to the degree to which they can demonstrate meaningful and longlasting behavior change, offer significant promise for social adjustment programming in the future.

\section{Maintenance}

\section{Tutorial}

The most common approach used with adolescents who have mild handicaps - in particular, in learning disabilities resource programs-has traditionally been tutoring. The objective of such a program is usually perceived as successful maintenance of students within the regular class curriculum. Thus the curriculum is focused on attending to their regular class needs.

A primary reason for the popularity of tutoring is motivational. Because students are concerned with success in the regular classroom, they often positively perceive it as a necessary form of support. In a related vein, they may prefer tutoring over other models (such as those with remedial foci) that are seen as more stigmatizing.

For similar reasons, regular class teachers, and parents, also tend to be supportive of a tutoring orientation. Regular education teachers believe that tutoring enables them to meet the needs of students with special needs who require extra assistance. Parents typically like this model because it allows their children to remain in regular education settings and still receive special help. When tutoring achieves its major goal of maintaining a student in the regular classroom, it should have a positive effect on grades and thus, at the secondary level, assist in fulfilling graduation requirements.

Despite the potential advantages of tutoring, it has a short-term emphasis, offering little of lasting value to students. An additional concern is whether the material learned is relevant to the students' future needs. In terms of training, a serious concern is the possible undertraining of special education teachers who must provide instruction in subjects (e.g., chemistry) for which they are insufficiently prepared. Similarly, the issue of overtraining is a concern because, beyond knowledge in subject matter, tutoring requires little need for advanced training in sophisticated in- structional techniques, and thus could be handled in many cases by paraprofessionals.

Tutoring's primary focus on short-term objectives underscores both its benefits and its most limiting disadvantage. Certainly all special education teachers must engage in some tutorial work to enhance their students' progress. For those students who require continual tutorial support, however, teachers should consider enlisting peers, paraprofessionals, and parent volunteers in the tutorial process.

\section{Learning Strategies}

The learning strategies concept emphasizes learning to learn and stresses the student's role as an active participant in the teaching/learning process (Weinstein \& Mayer, 1986). It therefore derives from a cognitive focus with an orientation to the thought processes of students in the learning process. Additionally, it places primary emphasis on the importance of transfer or generalization to other learning situations (content, instructors, and settings).

A substantial amount of the work that has resulted in application of the learning strategies approach to programs for students with disabilities was derived from the research efforts of Deshler and his colleagues at the University of Kansas Institute for Research on Learning Disabilities. As presented by Alley and Deshler (1979), learning strategies are used most appropriately in resource programs in which the main goal is generalization of skills to the regular classroom-hence the reason why this approach has been classified in this article as a maintenance model. A necessary factor for this approach to be successful would be cooperation between special education and regular classroom teachers.

Alley and Deshler (1979) described adolescent students who appear to benefit most from a learning strategies approach (LSA) as possessing the following characteristics: reading achievement above the third-grade level; ability to deal with symbolic as well as concrete learning tasks; and demonstration of at least average intellectual ability, defined as scoring in the 85-115 IQ range. Although the target group was defined in this fashion, components of the model should be effective for groups beyond this population-for example, younger students, as well as students whose achievement and intellectual levels are not commensurate with the levels as defined. Nevertheless, empirical validation of this proposal has rarely occurred to date.

A number of individual strategies and related instructional methods have been developed by individuals concerned about the effectiveness of this model with students 
experiencing learning problems (see Deshler \& Schumaker, 1986; Ellis \& Sabornie, 1986; Ellis, Lenz, \& Sabornie, 1987a, 1987b; Rooney, 1988). Deshler and Schumaker (1986) have suggested that a program of learning strategies instruction should provide training in approximately three or four strategies per year sequenced from within the three areas of acquisition, storage, and expression/demonstration of competence.

Given the work that has been done in developing the learning strategies approach, it now represents an appropriate programming option for older students. But certain considerations should be addressed when deciding whether to select this approach as a major component of the curriculum. First, if this type of model is used exclusively, it could result in limited attention to other curricular needs, especially in the area of functional skills. Second, many students with mild learning handicaps simply may not possess the entry-level skills necessary for successful acquisition and execution of strategic behaviors. Third, major consideration should be given to issues related to motivation in terms of "selling" to students the particular strategy being taught-especially given the difficulties that some students may have in becoming motivated to learn a strategy that provides primarily long-term rather than short-term benefits (Polloway et al., 1989).

Finally, the limited data base on efficacy of this model (see Deshler \& Schumaker, 1986) has to be expanded, particularly as related to generalization. This concern is important and could be voiced about many other curricula as well. Nevertheless, an emphasis on explicit training in the use of learning strategies seems to be very appropriate for students with limited academic skills (Weinstein \& Mayer, 1986).

\section{Functionality}

\section{Vocational Training Emphasis}

Although the two functional orientations-vocational training and adult outcomes-are clearly interrelated, they have a number of distinctive key features that warrant their separate discussions here. Vocational training has a tradition of being associated with secondary programming for students with mild/moderate retardation (e.g., Kolstoe \& Frey, 1965). Only recently have programs with vocational emphasis been considered more frequently for students identified as learning disabled or emotionally disturbed/behavior disordered as an alternative curricular focus at the secondary level.

The primary benefit of vocational training is its direct relationship to transitional efforts undertaken to prepare adolescents for postsecondary work environments. This feature may have motivational merit as well; for many students, enrollment in a vocational program may forestall the likelihood of dropping out of school. This concern is of particular importance given the fact that a substantial number of LD and BD students, in particular, are at risk for dropping out of school (Edgar, 1987).

Several related considerations are important to note at this point. Community-based learning opportunities are needed as an alternative to simulated vocational opportunities within a school setting. Community-based instruction implies programs that provide ideal environments for generalization and realistic job training opportunities. Similarly, a positive development in the vocational training domain has been the trend toward use of a supported employment model (e.g., Wehman, Renzaglia, \& Bates, 1985). This approach places students on the job and provides them with direct assistance from employment specialists/job coaches that can be faded out gradually over time as students become increasingly independent.

Several possible disadvantages with a vocational training approach include students' getting locked into a vocational track early in their secondary school program with little chance of ever getting out; limited training options available in traditional vocational education programs; the training of skills that have no or limited community validity; the assumption that students with various labels should be channeled automatically into vocational programs; and the absence of instructional planning and instruction following vocational assessment.

Another disadvantage involves the exclusion of students who are in other curricular programs, especially diplomatrack sequences. This is underscored by the reality that less than $4 \%$ of the enrollment in vocational education programs is composed of students with disabilities (Council of Chief State School Officers, 1986). Although these possible disadvantages can be overcome, they can present significant problems for the delivery of services to some students with mild disabilities.

\section{Adult Outcomes Orientation}

An adult outcomes orientation emphasizes a comprehensive life skills view of the postsecondary adjustment process. Although adult outcomes curricula may be focused less intensively on occupational training, they tend to be more responsive to varied concerns derived from the literature on adult adjustment (Cronin, 1988; Gerber \& Cronin, 1982) and the demands of adulthood (Knowles, 1978). As 
such, the model can never be seen as distinctly separate from social adjustment and vocational concerns.

An adult outcomes emphasis has a top-down orientation to curriculum development. This approach emphasizes skill development and knowledge acquisition that can be conceptualized as falling within two major domains (six topical areas), as represented in Figure 2, which must be considered in transitional planning (Patton \& Browder, 1988). The life domains represent the principal ways in which people organize their lives; the support domains refer to areas that must be addressed before individuals can reasonably take on the other responsibilities and activities of adulthood.

An apt illustration of an adult outcomes curriculum is the Adult Performance Level: Adaptation and Modification Project (APLAMP) (1975) (in LaQuey, 1981). This program contains 42 objectives, which form the basic elements for planning instruction and are associated with five general content areas: consumer economics, health, occupational knowledge, community resources, and government and law. The APLAMP serves as a core curriculum blending a focus on practical academics with direct applications to the specific demands of adulthood (Daniels \&

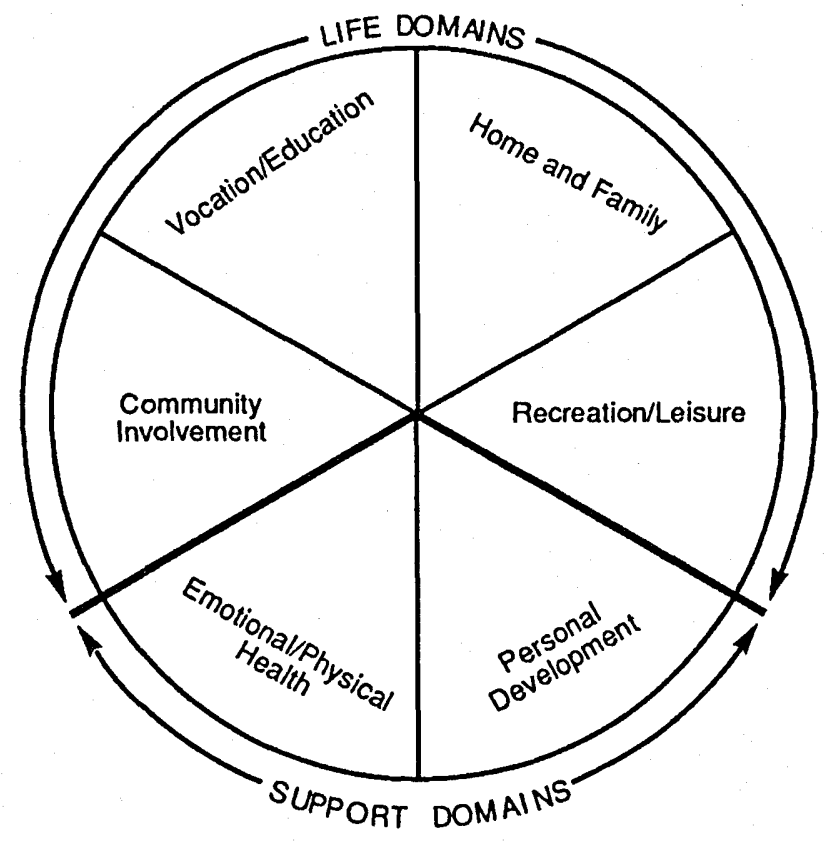

Source: Hawaii Transition Project. (1987). Major areas of transition. Honolulu: Author.

FIGURE 2

Adult Outcome Domains
Wiederholt, 1986). The resulting matrix of basic skills $X$ applications is similar in concept to other transitionally oriented curricula (see Smith \& Schloss, 1988).

For students who have had learning difficulties in school over 10 years or more, a curriculum whose primary focus shifts away from longstanding academic deficits and toward current skill needs and future life demands has potentially significant value. Adolescents frequently perceive an approach that emphasizes adult outcomes as more attractive-and it may have positive motivational results; the current trend toward students with mild handicaps dropping out of school is a most crucial motivational concern (Edgar, 1987; Lichtenstein, 1988).

A major caution that should be considered, however, is that unsystematic attention (i.e., inadequate scope and sequence) to adult outcomes may provide students with a curriculum of limited immediate or long-term benefit. Additionally, the definition of which community survival skills are most relevant has to be considered; attention to success within a given community therefore must be given serious consideration.

\section{DESIGNING COMPREHENSIVE CURRICULA}

The previous discussion highlighted alternative curricular models for consideration with students identified as mildly handicapped. Without question, they seldom are present in isolation, and their relevance varies significantly when evaluated for an individual student in a given situation. Based on initial work by Dangel (1981, cited by Vergason, 1983) and modified by Polloway et al. (1989) and Vergason (1983), Table 1 outlines key variables that should be considered in the process of making decisions with regard to general curricular orientations. These variables also influence choices related to combinations of the respective models for individual students or for groups of students with established similar needs.

Given the multiple variables to be considered, decision making clearly is not only an important, but also a complex, process. Matching a curricular model or models to traditional group labels represents an inappropriate practice reflecting the problematic nature of common labeling systems (Hallahan \& Kauffman, 1977; Smith, Price, \& Marsh, 1986). For example, the simple presumption that students with mild retardation cannot profit from remediation may prove to be just as invalid as the presumption that students with learning disabilities need primarily remedial programming regardless of age level.

Nevertheless, disregarding the area of exceptionality entirely may be fallacious because some cross-categorical 
TABLE 1

\section{Decision-Making Variables}

\section{Student Variables}

- cognitive-intellectual level

- academic skills preparedness

- academic achievement as determined by tests

- academic achievement as determined by class grades

- grade placement

- motivation and responsibility

- social interactions with peers and adults

- behavioral self-control

\section{Parent Variables}

- short- and long-term parental expectations

- degree of support provided (e.g., financial, emotional, academic)

- parental values toward education

- cultural influence (e.g., language, values)

\section{Regular Class Variables}

- teacher and nonhandicapped student acceptance of diversity (classroom climate)

- administrative support to integrated education

- availability of curricular variance

- accommodative capacity of the classroom

- flexibility of daily class schedules and units earned toward graduation

- options for vocational programs

\section{Special Education Variables}

- size of caseload

- availability of paraprofessionals or tutors in the classroom

- access to curricular materials

- focus of teacher's training

- consultative and materials support available

- related services available to students differences have been empirically determined (e.g., Cullinan \& Epstein, 1985; Edgar, 1987; Epstein \& Cullinan, 1983, 1984; Epstein, Cullinan, \& Gadow, 1986; Polloway \& Smith, 1988). These differences are most relevant if modified by attention to subgroups, identified by instructional needs, across these respective areas of exceptionality. By focusing on identifiable subgroups, the emphasis can appropriately shift from categorical labels to relevant programming.

The discussion that follows provides an orientation to help the curricular needs of subgroups of students. In each instance, the discussion is intended to provide a basis for initial consideration of program design for groups of students, which then must be modified to accommodate the needs of individuals.

\section{Elementary Students}

Most students with mild and moderate handicaps in the elementary school have a need for primary curricular emphasis on basic skills instruction to maximize academic achievement. At the same time, virtually all students identified as mildly retarded, emotionally disturbed, or behavior disordered, and many students identified as learning disabled, coincidentally need attention to social skills acquisition (Cullinan \& Epstein, 1985; Epstein, Bursuck, \& Cullinan, 1985; Polloway, Epstein, \& Cullinan, 1985; Zigmond \& Brownlee, 1980). At the same time, however, these deficit-oriented models should be counter-balanced with emphasis on students' individual strengths and positive traits.

The nature of curricular needs for students at this level, as well as their needs for placement within the least restrictive environment, must be weighed against the benefits of cross-categorical programming. In many instances curricular needs may be sufficiently similar for students labeled $\mathrm{LD}, \mathrm{BD}$, and EMR so that overattention to labeling will be counter-productive to the student's development (Smith, Price, \& Marsh, 1986). In addition, with appropriate modifications in programs within the regular classroom, and particularly with consultation support (l'dol \& West, 1987; West \& Idol, 1987), many of these needs can be met within regular class-based programs. Regardless of service delivery mode selected, two key programmatic elements need appropriate attention at this level: an introduction to career education with emphasis on career awareness and a focus on transitional variables as related to both placement in regular classes and movement to middle school settings (Epstein, Polloway, Patton, \& Foley, 1989; Jaquish \& Stella, 1986; Polloway, 1987). 


\section{Secondary Students}

For our purposes here, secondary students are defined as including those who are enrolled in middle, junior high, and senior high schools. Curricular differentiation is most critical with this population. To provide a perspective on variant needs, the succeeding sections are organized into curricularly focused subgroups that suggest a system of tracks. To some extent, these subgroups reflect the concept of alternative tracks, such as advocated by Minskoff (1971), in the formative years of the field of learning disabilities. As labeled here, the specific tracks are indexed against curricular needs for the subsequent environments into which the students are likely to proceed.

\section{College-Preparatory Track}

The population for whom curricular needs can be determined most clearly are students who have a reasonable opportunity of attending and being successful in postsecondary school settings. This population includes primarily students who currently are or previously were identified as learning disabled, as well as those labeled behavior disordered, who have acquired the academic prerequisites necessary for college admission and entry. Additionally, these are obviously students who, along with their parents, have the interest and commitment necessary for success at the postsecondary level. According to 1987 government statistics, $6.8 \%$ of college freshmen report having some disability-almost triple the number for 1978-and the percentage of self-identified college freshmen with learning disabilities is $1.2 \%$ (American Council on Education, 1987).

Development of an appropriate preparatory curriculum for these students should be in evidence during the middle school years and become a primary focus during high school. Curricular foci should include maximum participation in regular high school programs, not only for their generation of units toward a regular diploma but also for their attention to content necessary for college success. Second, attention should be given to the transitional needs of students moving into postsecondary settings. This should include attention to specific variables within the college setting that would require survival skills (e.g., time management and organizational skills) variant from those the individual students currently possess.

In terms of curricular focus, several general observations can be made. First, any needed remedial efforts should be broadly focused to include an emphasis on language development. In particular, intensive writing instruction should be encouraged because writing serves as the major basis for evaluation at the postsecondary level. A second key element of programming should be learning strategy training, especially with regard to organizational and study skills. Academic and career advising is a third necessary component of programming. Finally, college survival skills training, as alluded to earlier, would be a positive addition to the curriculum for these students (Patton \& Polloway, 1986).

\section{Functional Track $A$}

This track is for students with more significant learning problems and those with behavior problems whose difficulties within the regular school curriculum in middle and high school make them unlikely candidates for academic postsecondary programs, although they may participate in trade and technical training programs after high school. In addition, the track includes students who can be characterized as "traditional EMRs" or as having "high mild mental disabilities" (Sargent, 1988). This cross-categorical group of students is placed together because of a common need for curriculum that will prepare them for success in environments other than that of higher education. As used here, the sobriquet "traditional EMR" refers to the more adaptive students within the mild retardation range who historically have been placed in these programs.

In many states virtually no students remain in EMR programs to whom this appellation would apply (e.g., California); in other states (such as Alabama and Iowa) because of higher prevalence rates and a higher IQ cutoff criterion, respectively, a large number of students still classified as EMR are likely to be adaptive in terms of academic and social skills (see Patrick \& Reschly, 1982, for a discussion of interstate variance).

Clearly, as individuals in this amorphous track advance in age, intensive, relevant programming is increasingly needed. In many instances these needs will not be met easily in regular class-based programs that tend to provide them a nonfunctional curriculum (Edgar, 1987). This concern is particularly apt given the reality that students with mild handicaps who are seen as being capable of being mainstreamed are at significant risk for dropping out of school (Lichtenstein, 1988). Teachers report that a primary concern is for access to functional data-based curricula in independent living and vocational areas (Halpern \& Benz, 1987). Particularly appropriate would be programs focusing on work and transition to adulthood, and ecologically validated within the community.

Because social development is a key predictor of postschool adjustment (Epstein \& Cullinan, 1987), social 
skills instruction should be a core of the curriculum. Coincidentally, integration will take place at appropriate times in the instructional day so that these skills can be generalized to interactions with students who are not handicapped. The academic content of these programs should be designed and monitored for its potential contribution to mainstream success and adult outcomes.

\section{Functional Track B}

This track is designed for a lower functioning group including "new EMRs" (MacMillan, 1988)—students with mild retardation in states and school divisions in which substantial declassification efforts have left behind individuals who are "more patently disabled" (MacMillan \& Borthwick, 1980 , p. 155). With the declassification of students who might be considered adaptive and the concomitant inclusion of students traditionally placed in trainable classes, these programs are serving individuals who are quite different from those found previously in EMR programs and also quite different from students in other groups of students with mild handicaps (MacMillan, 1988; Polloway, Epstein, Cullinan, Patton, \& Luebke, 1986; Polloway \& Smith, 1988; Smith et al., 1986).

For this group, a transitionally focused curriculum is essential (Sargent, 1988; Smith \& Schloss, 1988). To promote transition, the curriculum must blend vocational training and social skills instruction with an adult outcomes emphasis. Academic training without direct, practical application, while justified for elementary and some middle school students, becomes an inappropriate focus for these students at the secondary level. An encouraging note is that few of these students apparently drop out of school (Edgar, 1987), perhaps because they may be characterized as compliant vis'-a-vis` attendance and thus are virtual "prisoners of the system" (Edgar, 1988).

Given the difficulty that some individuals from this group have with generalization, teachers must avoid the "train and hope" philosophy (Stokes \& Baer, 1977), in which few or no efforts are made to facilitate transfer of learning. Key foci should include community-based instructional programming, occupational placement, and follow-up. For many students, job coaching under the supported work model originally developed for individuals with more severe handicaps could be incorporated. Sargent (1988) suggests that the goal for all of these students should be part-time jobs prior to graduation. Given these considerations, educators can mold a curriculum to ensure its appropriate applicability for this population.

\section{"Tough-to-Call" Track}

The remaining subgroup of students with mild handicaps is one that continues to be difficult to categorize even within the admittedly loose designations listed earlier. This population would be considered inclusive particularly of learning disabled and emotionally disturbed/behavior disordered students at the middle school and early secondary school levels. Although most of these individuals subsequently will be likely to fall into Functional Track A (see previous discussion), it cannot be discounted that some may be candidates for higher education. In many instances these are individuals with unconfirmed interests, marginal academic achievement, and absence of commitment to particular career directions. They are commonly at risk for dropping out of school and no doubt comprise a substantial portion of the $42 \%$ dropout rate that Edgar (1987) reported for LD/BD students. Given the fact that school dropout rates have been reported highest after ninth grade (Zigmond, 1988), this population clearly should be considered at risk.

Any decisions about curricular needs for these students are difficult, but several assumptions can be posited. Guidance in terms of future options must be a part of the efforts the school staff undertakes. A key element should be transition planning, which should be initiated around ninth grade and should emphasize the importance of a subsequent environments perspective.

In terms of curricular foci, several specific judgments seem justifiable. Continuing basic skills remediation should be based on demonstrated efficacy in terms of student improvement, qualified by the assurance that it is provided in the form of intensive instruction. But the virtually exclusive reliance on a remedial approach, documented in research in IEPs (McBride \& Forgnone, 1985), should be modified to make the curriculum more comprehensive. Career education should be an important focus of curricular efforts, with particular attention to moving from the career awareness phase into exploration of alternative careers. Incorporation of a learning strategies approach should be entertained particularly to the extent that it may translate directly to success in the regular class curriculum. Because this population frequently is difficult to motivate, strategy instruction may have to be accompanied by motivational remediation with linkages between strategies learned and long-term benefits demonstrated.

Finally, as students move into the high school years, a shift in emphasis toward an adult outcomes model must be considered so that relevant life skills can become a major component of the curriculum. Given Edgar's (1987) report 
of an employment rate of only $30 \%$ for LD/BD dropouts, with $61 \%$ of the dropout population not engaged in employment or formal training, and Neel et al.'s (1988) similarly discouraging followup data on students with behavior disorders, it is imperative that preparation for life be initiated in middle school and become a priority in high school.

\section{CONCLUSION}

The commitment to comprehensive curriculum is an acknowledgement of the need for appropriate programs to meet both current and future needs. Decisions made about these programs should evaluate compatibility of curricular needs with programs that are categorical, non-categorical, or cross-categorical. Similarly, curriculum should be correlated with the specific service delivery model, with the initial decision made relative to curricular needs, followed by selection of the appropriate service delivery model.

For example, if a group of adolescents identified as learning disabled will have their needs met best through a learning strategy approach, a resource model becomes an appropriate placement. On the other hand, if a group of middle school students identified as mildly retarded has significant academic and social skill deficits, and overriding needs for career education, an argument for a special class-based program can be supported. As Zigmond and Sansone (1986) noted, each student be examined individually in terms of both the most appropriate placement and the most appropriate curricular model to be used.

\section{REFERENCES}

Adult Performance Level Project. (1975). Adult functional competency. Austin: University of Texas, Office of Continuing Education.

Alley, G.R., \& Deshler, D.D. (1979). Teaching the learning disabled adolescent: Strategies and methods. Denver: Love Publishing.

American Council on Education. (1987). American freshman: National norms for 1987. Washington, DC: Author.

Becker, W. (1984). Corrective reading program evaluated with secondary students in San Diego. Association for Direct Instruction News, 3(3), $1,23$.

Council of Chief State School Officers. (1986). Disabled students beyond school: A review of the issues, a position paper and recommendations for action. Washington, DC: Author.

Cronin, M.E. (1988). Adult performance outcomes/life skills. In G. Robinson, J.R. Patton, E.A. Polloway, \& L. Sargent (Eds.), Best practices in mental disabilities (Vol. 2) (pp. 39-520). Des Moines: Iowa State Department of Education.

Cullinan, D., \& Epstein, M.H. (1985). Teacher-related adjustment problems of mildly handicapped and nonhandicapped students. Remedial \& Special Education, 6, 5-11.

Daniels, J.L., \& Wiederholt, J.L. (1986). Preparing problem learners for independent living. In D.D. Hammill \& N.R. Bartel (Eds.), Teaching students with learning and behavior problems (4th ed., pp. 294-345). Austin: PRO-ED.

Deshler, D.D., \& Schumaker, J.B. (1986). Learning strategies: An in- structional alternative for low-achieving adolescents. Exceptional Children, 52, 583-589.

Deshler, D.D., Schumaker, J.B., Lenz, B.K., \& Ellis, E.S. (1984). Academic and cognitive interventions for LD adolescents (Part 2). Journal of Learning Disabilities, 17, 170-187.

Department of Education. (1987). Ninth annual report to Congress on the implementation of the Education of the Handicapped Act. Washington, DC: Author.

Edgar, E. (1987). Secondary programs in special education: Are many of them justifiable? Exceptional Children, 53, 555-561.

Edgar, E. (1988). Pressing problems in practices with secondary level learning disabled students. Paper presented at the 66th annual convention of the Council for Exceptional Children, Washington, DC.

Ellis, E.S., \& Sabornie, E.J. (1986). Teaching learning strategies to learning disabled students in post-secondary settings. Unpublished manuscript, University of South Carolina, Columbia, SC.

Ellis, E.S., Lenz, K., \& Sabornie, E.J. (1987a). Generalization and adaptation of learning strategies to natural environments: Part 1. Critical agents. Remedial \& Special Education, 8(1), 6-20.

Ellis, E.S., Lenz, K., \& Sabornie, E.J. (1987b). Generalization and adaptation of learning strategies to natural environments: Part 2. Research into practice. Remedial \& Special Education, 8(2), 6-23.

Engelmann, A., Becker, W.C., Hanner, S., \& Johnson, G. (1980). Corrective reading program. Chicago: Science Research Associates.

Epstein, M.H., Bursuck, W., \& Cullinan, D. (1985). Patterns of behavior problems among the learning disabled: 2 . Boys aged 12-18, girls aged 6-11, girls aged 12-18. Learning Disability Quarterly, 8, 123131.

Epstein, M.H., \& Cullinan, D. (1983). Academic performance of behaviorally disordered and learning disabled pupils. Journal of Special Education, 17, 303-308.

Epstein, M.H., \& Cullinan, D. (1984). Behavior problems of mildly handicapped and normal adolescents. Journal of Clinical Child Psychology, 13, 33-37.

Epstein, M.H., \& Cullinan, D. (1987). Effective social skills curricula for behaviorally disordered students. Pointer, 31(2), 21-24.

Epstein, M.H., Cullinan, D., \& Gadow, K.D. (1986). Teacher ratings of hyperactivity in learning disabled, emotionally disturbed, and mentally retarded children. Journal of Special Education, 20, 219 230.

Epstein, M.H., Polloway, E.A., Patton, J.R., \& Foley, R. (1989). Mild retardation: Student characteristics and services. Education \& Training in Mental Retardation, 24, 7-16.

Foster, S.L., \& Ritchey, W.L. (1979). Issues in the assessment of social competence. Journal of Applied Behavior Analysis, 12, 625-638.

Gerber, P., \& Cronin, M.E. (1982). Preparing the learning disabled adolescent for adulthood. Topics in Learning \& Learning Disabilities, 2(3), 55-68.

Gregory, R.P., Hackney, D., \& Gregory, N.M. (1982). Corrective reading programme: An evaluation. British Journal of Educational Psychology, 52, 33-50.

Gresham, F.M. (1982). Misguided mainstreaming: The case for social skills training with handicapped children. Exceptional Children, 48 , 420-433.

Gresham, F.M. (1983). Social skills assessment as a component of mainstreaming placement decisions. Exceptional Children, 49, 331-336.

Gresham, F.M. (1984). Social skills and self-efficacy for exceptional children. Exceptional Children, 51, 253-261.

Hallahan, D.P., \& Kauffman, J.M. (1977). Labels; categories, behaviors: ED, LD and EMR reconsidered. Journal of Special Education, 11, 129-149.

Halpern, A.W., \& Benz, M.R. (1987). A statewide examination of special education for students with mild disabilities: Implications for the high school curriculum. Exceptional Children, 54, 122-129.

Hoover, J.J. (1988). Curriculum adaptation for students with learning 
and behavior problems: Principles and practices. Lindale, TX: Hamilton Publications.

Idol, L., \& West, J.F. (1987). Consultation in special education (Part 2): Training and practice. Journal of Learning Disabilities, 20, 474-494.

Jaquish, C., \& Stella, M.A. (1986). Helping special needs students move from elementary to secondary school. Counterpoint, 7(1), 1.

Knowles, M. (1978). The adult learner: A neglected species (2nd ed.). Houston: Gulf Publishing.

Kolstoe, O.P., \& Frey R.M. (1965). A high school work-study program for mentally subnormal students. Carbondale, IL: Southern Illinois University Press.

LaQuey, A. (1981). Adult performance level adaptation and modification project. Austin, TX: Educational Service Center, Region 13.

Lichtenstein, S. (1988). Special education dropouts. Washington, DC: ERIC Clearinghouse on Educational Management.

MacMillan, D.L. (1988). New EMRs. In G.R. Robinson, J.R. Patton, E.A. Polloway, \& L. Sargent (Eds.), Best practices in mental disabilities (Vol. 2). Des Moines: Iowa State Department of Education.

MacMillan, D.L., \& Borthwick, S. (1980). The new educable mentally retarded population: Can they be mainstreamed? Mental Retardation, $18,155-158$.

Masters, L.F., \& Mori, A.A. (1986). Teaching secondary students with mild learning and behavior problems. Rockville, MD: Aspen.

McBride, J.W., \& Forgnone, C. (1985). Emphasis of instruction provided LD, EH, and EMR students in categorical and cross-categorical programming. Journal of Research \& Development in Education, 18(4), 50-54.

Meichenbaum, D. (1980). Cognitive behavior modification with exceptional children: A promise yet unfulfilled. Exceptional Education Quarterly, 1(1), 83-88.

Meichenbaum, D. (1983). Teaching thinking: A cognitive-behavioral approach. In Interdisciplinary voices in learning disabilities and remedial education. Austin, TX: Pro-Ed.

Meyen, E.L., \& Lehr, D.H. (1980). Evolving practices in assessment and intervention for mildly handicapped adolescents: The case for intensive instruction. Exceptional Education Quarterly, 1(2), 19-26.

Minskoff, J.G. (1971). Learning disabled children at the secondary level: Educational programming in perspective. In J. Arena (Ed.), The child with learning disabilities: His right to learn. Proceedings of the Eighth Annual International ACLD Conference, Chicago.

Neel, R.S., Meadows, N., Levine, P., \& Edgar, E.B. (1988). What happens after special education: A statewide follow-up study of secondary students who have behavioral disorders. Behavioral Disorders, 13, 209-216.

Patrick, J.L., \& Reschly, D.J. (1982). Relationship of state educational criteria and demographic variables to school-system prevalence of mental retardation. American Journal of Mental Deficiency, 86, 351360.

Patton, J.R., \& Browder, P.M. (1988). Transitions into the future. In B.L. Ludlow, A.P. Tumbull, \& R. Luckasson (Eds.), Transitions to adult life for people with mental retardation: Principles and practices (pp. 293-311). Baltimore: Paul H. Brookes.

Patton, J.R., \& Polloway, E.A. (1987). Analyzing college courses: Academic planning for the LD college student. Academic Therapy, $22,273-280$.

Polloway, E.A. (1987). Early age transition: Transitional services for mildly retarded individuals. In R. Ianacone \& R.A. Stodden (Eds.), Transitional issues and directions for individuals who are mentally retarded (pp. 11-24). Reston, VA: CEC-MR.

Polloway, E.A., Epstein, M.H., \& Cullinan, D. (1985). Prevalence of behavior problems among educable mentally retarded students. Education \& Training of the Mentally Retarded, 20, 3-13.

Polloway, E.A., Epstein, M.H., Cullinan, D., Patton, J.R., \& Luebke, J. (1986). Demographic, social and behavioral characteristics of students with educable mental retardation. Education \&Training of the Mentally Retarded, 21, 127-134.

Polloway, E.A., Epstein, M.H., Polloway, C.H., Patton, J.R., \& Ball, D.W. (1986). Corrective reading program: An analysis of effectiveness with learning disabled and mentally retarded children. Remedial \& Special Education, 7(4), 41-47.

Polloway, E.A., Patton, J.R., Payne, J.S., \& Payne, R.A. (1989). Strategies for teaching learners with special needs (4th ed.). Columbus, $\mathrm{OH}$ : Merrill.

Polloway, E.A., \& Smith, J.D. (1988). Current status of the mild mental retardation construct: Identification, placement and programs. In M.C. Wang, M.C. Reynolds, \& H.J. Walberg (Eds.), The handbook of special education: Research and practice (Vol. 2, pp. 1-22). Oxford, England: Pergamon Press.

Rooney, K. (1988). Independent strategies for efficient study. Richmond, VA: J.R. Enterprises.

Sargent, L.E. (1988). Ideas for future programming in mental disabilities. In J.R. Patton, G.A. Robinson, \& D. Browder (Eds.), Setting our agenda: Proceedings of the lowa Conference on futures in mental disabilities. Des Moines: State of Iowa Department of Education.

Shea, T.M., \& Bauer, A.M. (1987). Teaching children and youth with behavior disorders (2nd ed.). Englewood Cliffs, NJ: Prentice-Hall.

Smith, M.A., \& Schloss, P.J. (1988). Teaching to transition. In P.J. Schloss, C.A. Hughes, \& M.A. Smith (Eds.), Community integration for persons with mental retardation (pp. 1-16). Boston: College-Hill.

Smith, T.E.C., Price, B.J., \& Marsh, G.E. (1986). Mildly handicapped children and adults. St. Paul: West Publishing.

Stevens, R., \& Rosenshine, B. (1981). Advances in research on teaching. Exceptional Education Quarterly, 2(1), 1-9.

Stokes, F., \& Baer, D.M. (1977). An implicit technology of generalization. Journal of Applied Behavior Analysis, 10, 349-367.

Thorne, M.T. (1978). "Payment for reading": The use of the "Corrective Reading Scheme" with junior maladjusted boys. Remedial Education, $13(2), 87-90$.

Vergason, G.A. (1983). Curriculum content. In E.L. Meyen, G.A. Vergason, \& R.J. Whelan (Eds.), Promising practices for exceptional individuals: Curriculum implications (pp. 127-142). Denver, Love Publishing.

Wehman, P., Renzaglia, A., \& Bates, P. (1985). Functional living skills for moderately and severely handicapped individuals. Austin, TX: Pro-Ed.

Weinstein, C., \& Mayer, B. (1986). Learning strategies. In M.C. Wittrock (Ed.), Handbook of research on teaching (Vol. 3). New York: Macmillan.

West, J.F., \& Idol, L. (1987). School consultation (Part 1): An interdisciplinary perspective on theory, models and research. Journal of Learning Disabilities, 20, 388-408.

Zigmond, N. (1988). Pressing problems in practices with secondary level learning disabled students. Paper presented at the 66th annual convention of the Council for Exceptional Children, Washington, DC.

Zigmond, N., \& Brownlee, J. (1980). Social skills training for adolescents with learning disabilities. Exceptional Education Quarterly, 1(2), 77 84.

Zigmond, N., \& Sansone, J. (1986). Designing a program for the learning disabled adolescent. Remedial \& Special Education. 7(5) 13-17 